
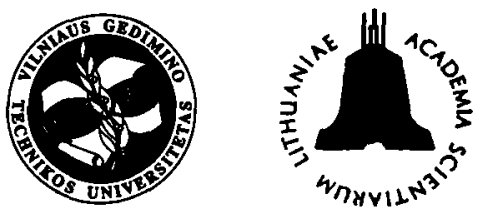

JOURNAL OF CIVIL ENGINEERING AND MANAGEMENT

http:/www.vtu.lt/english/editions

2003, Vol IX, No 2, $115-121$

\title{
AN INFLUENCE OF OUTDOOR TEMPERATURE ON THERMAL PERFORMANCE OF WINDOWS WITH A LOW-EMISSIVITY GLAZING
}

\author{
Arūnas Burlingis ${ }^{1}$, Birutė Samajauskiené $\dot{e}^{2}$, Juozas Ramanauskas ${ }^{3}$ \\ Laboratory of Building Thermal Physics, Institute of Architecture and Construction, \\ Tunelio g. 60, LT-3035 Kaunas, Lithuania \\ 'E-mail: silfiz@asi.lt; ${ }^{2}$ E-mail:bisama@centras.lt; ${ }^{3} E$-mail:r_juozas@centras.lt
}

Received 19 Aug 2002; accepted 16 Jan 2003

\begin{abstract}
Heat economy is a pressing issue in all countries with severe climate. The most frequent method to solve the problem is to decrease heat losses in buildings by increasing the thermal resistance of enclosures. The most popular measure to improve windows is the use of low-emissivity coatings and inert gases. The U-value of such glazing unit is mostly dependent on the possibility of coating to reflect IR (infrared) radiation. These coatings are very effective when surface temperatures are high. During service of windows with a change of outdoor conditions (mostly temperature and wind), an U-value of it will suffer changes. The aim of this article is to show an influence of outdoor temperature on thermal performance of windows with a low-emissivity glazing and to determine the differences of declared and design U-values of modern effective windows substantial enough to introduce a concept of a normative design U-value for windows in Lithuania. We have found that differences between declared and design values (under the conditions of Lithuania) reach on average up to $17 \%$ for double glazed IG units with one low-E coating. Thus in case of very effective windows, it makes sense to introduce a concept of design U-value for windows in our country.
\end{abstract}

Keywords: glazing, glass unit, thermal resistance, density of heat flow rate, thermal transmittance through insulating glass units, low-emissivity coating.

\section{Introduction}

Heat economy is a topical issue in all countries with a severe climate. It helps to save the limited energy resources and preserve the environment. The most frequent method used to solve the problem is to decrease heat losses in buildings by increasing the thermal resistance of enclosures such as walls, floors, attics etc. These losses are dependent on thickness of layers and their thermal conductivities [1-3]. Unfortunately, those dependencies are not effective for windows or other transparent multilayer elements of a building envelope. The above mentioned enclosures transmits heat in three ways: by convection, by conduction and by radiation (Fig 1). For example, a typical double-glazed window radiation accounts for up to $2 / 3$ of the total heat loss through it while conductive and convective heat transfer express the remaining $1 / 3$ [4]. In this case the thermal resistance ( $R$-value) of a glazing results from the airspace between panes of glass and from thin layers of air at the inside and outside surfaces of an assembly that slows down the heat transfer. The glass itself has negligible resistance to heat flow [5] and may be neglected.

Thus, the thermal resistance of glazing can be expressed approximately by the following:

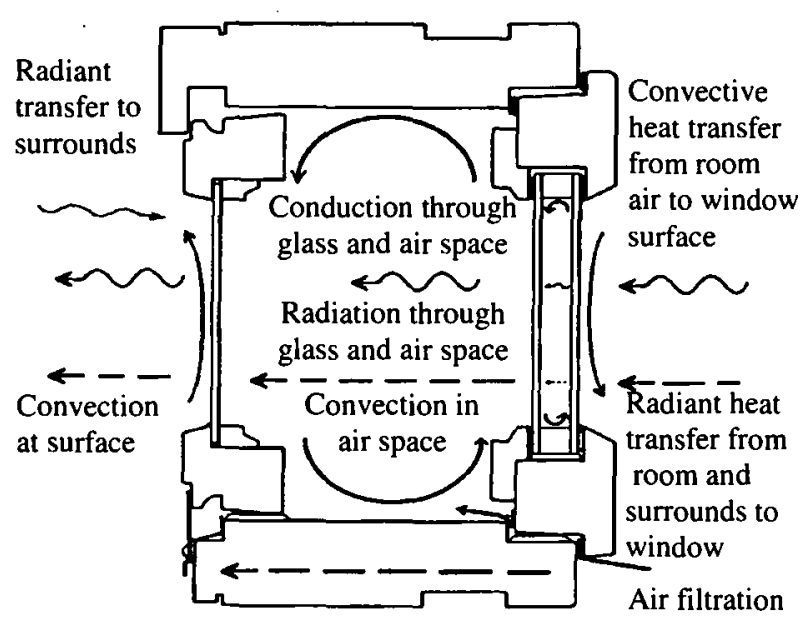

Fig 1. Window heat loss mechanisms

$$
R_{\text {glazing }} \cong R_{\text {se }}+R_{\text {air space }}+R_{s i}
$$

One focus for improving the thermal performance of windows has been to control thermal radiation losses, because radiation constitutes about $40 \%$ of the total heat transfer [6]. The use of low-emissivity coatings for glazing decreases the amount of heat transferred by radia- 
tion. Heat loss due to convection can be decreased by use of heavier than air one or two-atomic gases, which have negligible reradiation feature. An increased thermal resistance can also be achieved using rather esoteric technologies such as aerogels and evacuated glazings [7].

Low-emissivity glazings were pioneered in the late sixties and early seventies [8]. A batch sputtering technique was used in the USA to deposit indium oxide coatings on glass. Electrically conductive coatings of this type were used to heat glass and improve visibility [9]. Advances in films, coatings and production methods have improved the quality and reduced the cost of low-emissivity glazing. In 1985 low-emissivity glazings constituted $5 \%$ of the USA residential market [10]. It was predicted that in 1988 this would be increased up to $25 \%$ [11].

In Lithuania today heat energy conservation and diminishing heat losses through enclosures in buildings is also an urgent issue. Since 1992, after validation of new requirements for heat conservation through building envelope in the new building code RSN143-92 "Thermal technics of building enclosures" [12] and later in 1999 after STR2.05.01: 1999 "thermal technique of envelopes of the buildings" [3] was issued, a required value for heat transfer coefficient of most enclosures was tightened and reduced some times, but not for windows. It happened because of restricted economically paying back and technical possibilities for improving heat transfer coefficient of windows [13].

With a change of economic situation in Lithuania and improvement of technologies, more and more effective heat conserving measures for windows have been used (low-emissivity coatings applied to glass, inert gas filling a cavity of a glazing unit, etc). The most popular measures include the use of low-emissivity coatings and inert gas [14]. The U-value of such glazing unit is mostly dependent on possibility of coating to reflect IR (infrared) radiation. It is known that these coatings are very effective when surface temperatures of it are high [15]. During service of windows with a change of outdoor conditions (mostly temperature and wind), a U-value of it will change too.

This is rather new subject of investigation, because we did not find any article concerning this issue and also in discussions with some Swedish, Estonian, Russian researchers we have understood that this subject at the moment is of no interest. American researchers working in the field of window investigation do not show the activity either. This is quite understandable because in the USA the declared U-value of window is measured or calculated with the outdoor temperature of minus $17,8^{\circ} \mathrm{C}$, ie quite close to the real design conditions. Only EN standard [16] mentions the possibility for design purposes to use other environmental conditions than those declared.

Why is this subject so urgent today? Heat losses of buildings are calculated more and more precisely. So a heating source power is to be chosen also with a smaller reserve. Now it is recommended to choose a heating power just with a reserve of $10 \%$. This requires to be very cautious evaluating thermal insulating values of building elements, of windows too. In most cases heat losses through windows for apartments reach about 25 to $30 \%$ of total heat losses, even up to about $40 \%$ for separate apartments located in a middle floors of multistorey dwellings. In public buildings the area of windows is bigger and have a tendency to grow. For them the problem of correct calculation of heat losses is more evident.

In modern windows, with IG units having very effective low-emissivity coatings, it becomes clear that during the coldest period of a heating season the declared and design U-value should evidently differ. If it is not so important to calculate heat losses of a whole heating season, it may become an important issue during the coldest period considering whether it would be enough power for a heating source. For ordinary thermal insulating materials and IG units (without low-emissivity coatings) thermal insulating features become better with lowering their mean temperature and the declared values can be taken as design values. But for IG units with effective low-emissivity coatings with lowering a mean temperature, their thermal insulating features become worse.

Therefore it would be necessary to introduce a term of a design U-value for windows as it is used for other building elements. As we have mentioned before, standard EN 673 [16] clearly writes about a possibility to apply or introduce a design $U$-value for windows if it is necessary.

The aim of this article is to define the influence of outdoor temperature on thermal performance of windows with low-emissivity glazing and to determine the differences of declared and design U-values of modern effective windows substantial enough to introduce a concept of a normative design U-value for windows, neglecting an impact of ageing.

\section{Means of investigation}

\subsection{Numerical simulation of heat transfer through IG units and simplified calculation theory}

Simulation was provided by a numerical method of solution for a model described in [17]. This program (WINDOW 4.1) has been developed by the Windows and Daylighting Group at Lawrence Berkeley Laboratory for calculating total window thermal performance indices (ie U-values, solar heat gain coefficients, shading coefficients and visible transmittances). The program calculates a combined heat flow (conduction, convection and radiation) by solving two-dimensional heat transfer using the finite difference method.

The U-value of a glazing without edge effects, under steady-state conditions between environmental temperatures on each side is found by [16]: 


$$
\frac{1}{U}=\frac{1}{h_{e}}+\frac{1}{h_{t}}+\frac{1}{h_{i}},
$$

where $h_{e}$ and $h_{i}$ are the external and internal surface heat transfer coefficients; $h_{t}$ is the total thermal conductance of glazing unit:

$$
\frac{1}{h_{t}}=\sum_{1}^{n} \frac{1}{h_{s}}+\sum_{1}^{m} d_{j} r_{j},
$$

where $n$ is the number of spaces; $d_{j}$ - thickness of each material layer; $r_{j}$ - thermal resistivity of each material ( $r=1,0 \mathrm{~m} \cdot \mathrm{K} / \mathrm{W}$ of soda lime glass); $m$ - number of material layers. $h_{s}$ - thermal conductance of each gas space:

$$
h_{s}=h_{r}+h_{g}
$$

where $h_{r}$ is the radiation conductance; $h_{g}$ - gas conductance.

The radiation conductance between two surfaces is given by:

$$
h_{r}=4 \sigma\left(\frac{1}{\varepsilon_{1}}+\frac{1}{\varepsilon_{2}}-1\right)^{-1} T_{m}^{3},
$$

where $\sigma$ is the Stefan-Boltzmann's constant $\left(\sigma=5,67 \cdot 10^{-8} \mathrm{~W} /\right.$ $\left.\mathrm{m}^{2} \mathrm{~K}^{4}\right) ; T_{m}$ - mean absolute temperature of the gas space; $\varepsilon_{1}$ and $\varepsilon_{2}$ - corrected emissivities at $T_{m}$.

The equation (5) indicates that a heat transfer through a space increases with increasing a mean space temperature.

Convection is a heat transfer due to moving and mixing of particles of fluids with different temperatures. In natural convection this movement is caused by density difference due to temperature differences, with the warmer portions rising and the colder, denser portions sinking. If the driving forces are external, such as wind or ventilation, the heat transfer is referred to as forced convection. The convective heat transfer through a gas layer is mainly due to conduction [18] and it can be expressed by gas conductance $h_{g}$.

The gas conductance is given by [18]:

$$
h_{g}=N u_{s}^{\lambda},
$$

where $s$ is the width of the space; $\lambda$ - thermal conductivity; $\mathrm{Nu}$ - Nusselt number:

$$
N u=A(G r \cdot P r)^{n},
$$

where $A$ is a constant (for vertical glazing $\mathrm{A}$ is 0,035 ); $n$ - exponent (for vertical glazing $n$ is 0,38 ); $G r-$ Grashof number; $\mathrm{Pr}$ - Prandtl number:

$$
\begin{aligned}
& G r=\begin{array}{c}
9,81 \cdot s^{3} \cdot \Delta T \cdot \rho^{2} \\
T_{m} \cdot \mu^{2}
\end{array} ; \\
& \operatorname{Pr}=\frac{\mu \cdot c}{\lambda},
\end{aligned}
$$

where $\Delta T$ is the temperature difference between glass surfaces bounding the gas space; $\rho$ - density; $\mu-$ dy- namic viscosity; $c$ - specific heat capacity; $T_{m}$ - mean temperature.

If the Nusselt number calculated by equation (7) is less than 1,0 , then it is equated to 1,0 calculating conductance $h_{g}$ in equation (6).

The corrected emissivities $\varepsilon$ of the surfaces bounding the closed spaces are required to calculate the radiation conductance $h_{r}$ in equation (5). For uncoated soda lime glass surfaces or for soda lime glass surfaces with coatings which have no effect on the emissivity, the corrected emissivity to be used is 0,837 . For other coated surfaces the normal emissivity $\varepsilon_{n}$ shall be determined with an infrared spectrometer. Then the corrected emissivity is determined from the normal as described in annex A.2 [16].

Declared values: standardised boundary conditions

To have a possibility to compare different glazings and windows it is agreed to give their U-values in some standardised boundary conditions, which are called declared values.

The standardised boundary conditions for declared values are:

$r$ thermal resistivity of soda lime glass $\quad 1,0 \mathrm{mK} / \mathrm{W}$

$\varepsilon \quad$ corrected emissivity of uncoated

soda lime and borosilicate glass

surface

$\Delta T$ temperature difference between bounding glass surfaces

$T_{m} \quad$ mean temperature of gas space

$\sigma$ Stefan-Boltzmann's constant

$h_{e} \quad$ external heat transfer coefficient for uncoated soda lime glass surfaces

$h_{i} \quad$ internal heat transfer coefficient for uncoated soda lime glass surfaces

A constant

$n$ exponent
$15 \mathrm{~K}$

$5,67 \times 10^{-8}$ $\mathrm{W} /\left(\mathrm{m}^{2} \mathrm{~K}^{4}\right)$

$23 \mathrm{~W} /\left(\mathrm{m}^{2} \mathrm{~K}\right)$

$8 \mathrm{~W} /\left(\mathrm{m}^{2} \mathrm{~K}\right)$

0,035

0,38
$283 \mathrm{~K}$

\subsection{Verifying laboratory test and calculation}

Specimens. Measurements of U-value were made on $500 \times 500 \mathrm{~mm}$ IG unit with two panes and one 16 mm space, filled up with $100 \%$ argon gas. One pane was with infrared low-emissivity coating. The second IG unit was the same, but filled up with air.

Equipment. In the current study verifying U-value measurement was made using a heat flow meter apparatus with $250 \times 250 \mathrm{~mm}$ central measuring area, which conforms to standard ISO 8301 [19].

Normal emissivity of low E coating was measured with emissometer model AE-RD1 (Comperipherials, Inc.), accuracy $\pm 0,3 \%+1$ digit, repeatability $\pm 0,01$ emittance units.

Measurement. The values of heat flow density and temperatures in the sample were measured under stationary declared environmental conditions in vertical position, when the mean temperature of IG unit is about $10^{\circ} \mathrm{C}$. 
After measurement of U-value, the IG unit was disassembled and normal emissivity of low-E coating was measured.

Results. For calculations the measured emissivity of low-E coating was used. The measured, calculated and programme simulated values of thermal transmittance of IG units appeared quite close to each other. This convinced us that WINDOW 4.1 programme simulations are really secure and accurate (Table 1).

Table 1. Comparison of U-values of IG units obtained using different methods of investigation

\begin{tabular}{|c|c|c|c|}
\hline Method & $\varepsilon_{\mathrm{n}}$ & $\begin{array}{c}\text { U-value } \\
\text { 4-16Ar-4(infr) }\end{array}$ & $\begin{array}{c}\text { U-value } \\
4-16-4 \text { (infr) }\end{array}$ \\
\hline Measured values & \multirow{3}{*}{0,08} & 1,25 & 1,55 \\
\hline $\begin{array}{l}\text { Simplified EN } \\
673 \text { calculation }\end{array}$ & & 1,26 & 1,52 \\
\hline $\begin{array}{l}\text { WINDOW } 4.1 \\
\text { simulation }\end{array}$ & & 1,27 & 1,52 \\
\hline
\end{tabular}

\subsection{Objects of investigation}

There is a huge number of different IG units with different parameters (Table 2). We are going to investigate just a limited number of them.

Table 2. Parameters of IG units under investigation

\begin{tabular}{|l|l|}
\hline \multicolumn{1}{|c|}{ Parameter } & \multicolumn{1}{|c|}{ Values of a parameter } \\
\hline Normal emissivity & 0,$04 ; 0,08 ; 0,2$ \\
\hline Gas filled & Argon; air; Krypton \\
\hline Spacer width, mm & $12 ; 16 ; 19 ; 24$ \\
\hline \multirow{3}{*}{ Boundary conditions } & $\begin{array}{l}\text { a) declared } \\
\text { b) design for Vilnius city: } \\
\text { - wind speed } 2,5 \mathrm{~m} / \mathrm{s} .\end{array}$ \\
\hline Number of panes & 2 \\
\hline $\begin{array}{l}\text { Number of low-E } \\
\text { coatings }\end{array}$ & 1 \\
\hline Position & Vertical \\
\hline
\end{tabular}

We have mentioned before that in [16] it is suggested to calculate a design U-value, because in building design the use of declared value may not always be sufficiently accurate. Here it is said that the design value shall be calculated appropriate to the position of the glazing and the environmental conditions, ie using correct boundary values of $h_{s}, h_{e}$ and $h_{i}$ which shall be stated.

The design boundary conditions were taken for Vilnius city [20, tables 2.11 and 5.5] because of two reasons: the first - only for Vilnius there are wind speed data dependent on outdoor air temperature, the second - design outdoor temperature varies throughout Lithuania from $-20{ }^{\circ} \mathrm{C}$ to $-23{ }^{\circ} \mathrm{C}$, ie differences are rather small and there is no reason to use design conditions for every city.

\section{Results of investigation and discussion}

Below in Table 3 and Figs 2-5 there are the results of numerical simulation of heat transfer through IG unit dependent on outdoor temperature. Wind speed outdoors $v_{o}$ is related with outdoor temperature $t_{o}$ and is taken from [20, Table 5.5]. For low-E coating normal emissivity values $e_{n}$ are chosen as mostly used values in practice.

Table 3. Heat transfer values through IG unit dependent on outdoor temperature

\begin{tabular}{|c|c|c|c|}
\hline \multirow[b]{2}{*}{ IG unit } & \multirow[b]{2}{*}{$\varepsilon_{n}$} & \multicolumn{2}{|c|}{ U-value } \\
\hline & & $\begin{array}{c}t_{0}=0^{\circ} \mathrm{C}, \\
v_{o}=4,5 \mathrm{~m} / \mathrm{s}\end{array}$ & $\begin{array}{l}t_{0}=-23^{\circ} \mathrm{C}, \\
v_{0}=2,5 \mathrm{~m} / \mathrm{s}\end{array}$ \\
\hline 4-12Ar-4infr & 0,04 & 1,23 & 1,33 \\
\hline 4-12-4infr & 0,04 & 1,58 & 1,61 \\
\hline $4-12 \mathrm{Kr}-4 \mathrm{infr}$ & 0,04 & 1,05 & 1,22 \\
\hline 4-12Ar-4infr & 0,08 & 1,34 & 1,40 \\
\hline 4-12-4infr & 0,08 & 1,67 & 1,69 \\
\hline $4-12 \mathrm{Kr}-4 \mathrm{infr}$ & 0,08 & 1,17 & 1,31 \\
\hline 4-12Ar-4infr & 0,2 & 1,64 & 1,64 \\
\hline 4-12-4infr & 0,2 & 1,93 & 1,89 \\
\hline $4-12 \mathrm{Kr}-4$ infr & 0,2 & 1,48 & 1,56 \\
\hline 4-16Ar-4infr & 0,04 & 1,18 & 1,36 \\
\hline 4-16-4infr & 0,04 & 1,43 & 1,64 \\
\hline $4-16 \mathrm{Kr}-4 \mathrm{infr}$ & 0,04 & 1,09 & 1,27 \\
\hline 4-16Ar-4infr & 0,08 & 1,28 & 1,44 \\
\hline 4-16-4infr & 0,08 & 1,53 & 1,71 \\
\hline 4-16Kr-4infr & 0,08 & 1,20 & 1,35 \\
\hline 4-16Ar-4infr & 0,2 & 1,28 & 1,67 \\
\hline 4-16-4infr & 0,2 & 1,79 & 1,91 \\
\hline 4-16Kr-4infr & 0,2 & 1,51 & 1,59 \\
\hline 4-19Ar-4infr & 0,04 & 1,20 & 1,39 \\
\hline 4-19-4infr & 0,04 & 1,45 & 1,67 \\
\hline 4-19Kr-4infr & 0,04 & 1,12 & 1,30 \\
\hline 4-19Ar-4infr & 0,08 & 1,30 & 1,47 \\
\hline 4-19-4infr & 0,08 & 1,54 & 1,74 \\
\hline 4-19Kr-4infr & 0,08 & 1,23 & 1,38 \\
\hline 4-19Ar-4infr & 0,2 & 1,59 & 1,69 \\
\hline 4-19-4infr & 0,2 & 1,80 & 1,94 \\
\hline 4-19Kr-4infr & 0,2 & 1,53 & 1,62 \\
\hline 4-24Ar-4infr & 0,04 & 1,23 & 1,43 \\
\hline 4-24-4infr & 0,04 & 1,49 & 1,72 \\
\hline 4-24Kr-4infr & 0,04 & 1,15 & 1,33 \\
\hline 4-24Ar-4infr & 0,08 & 1,34 & 1,50 \\
\hline 4-24-4infr & 0,08 & 1,58 & 1.78 \\
\hline 4-24Kr-4infr & 0,08 & 1,28 & 1,42 \\
\hline 4-24Ar-4infr & 0,2 & 1,62 & 1,72 \\
\hline 4-24-4infr & 0,2 & 1,83 & 1,97 \\
\hline 4-24Kr-4infr & 0,2 & 1,55 & 1,65 \\
\hline $4-16-4$ & - & 2,57 & 2,50 \\
\hline
\end{tabular}

For design U-values of other building components than windows the outdoor surface resistance is taken the same as for declared U-values, ie $0,04\left(\mathrm{~m}^{2} \mathrm{~K}\right) / \mathrm{W}$, which corresponds to about $4-5 \mathrm{~m} / \mathrm{s}$ wind speed. For calculating window design U-value it would be incorrect to use this outdoor surface resistance value because of a relatively low R-value of windows itself.

The curves in Fig 3 are waved because of different outdoor wind speeds when calculating the design U-val- 


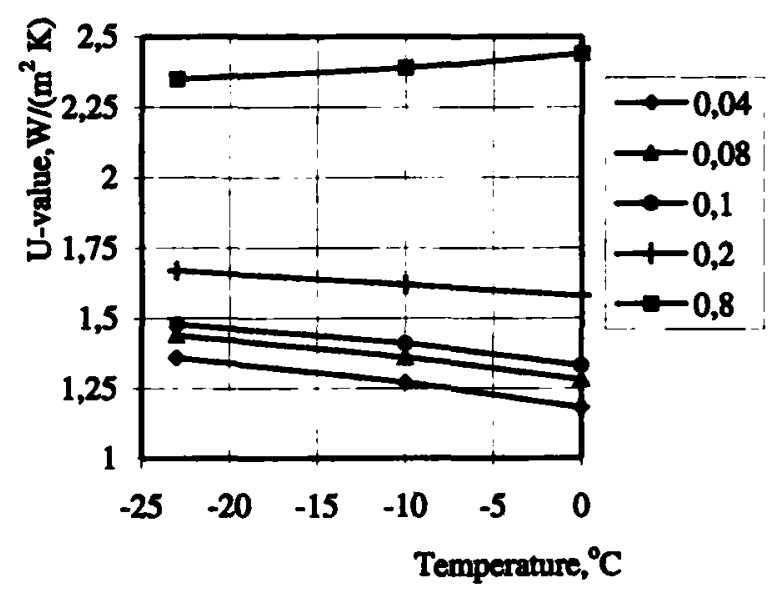

Fis 2. The dependence of U-values of IG units in outdoor temperature and emissivity of low-E coating, (4-16Ar-4infr)

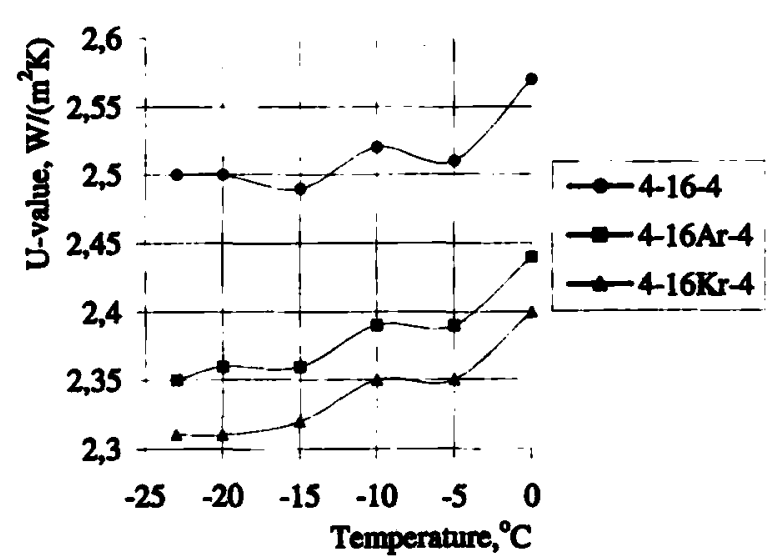

Fig 3. The dependence of U-values of IG units without low-E coating in outdoor temperature and filled gases

ues. Here we can see that taking the different external surface heat transfer coefficients, which are dependent on a wind speed, makes the observable influence on the thermal transmittances of ordinary IG units without any effective low-E coating. Thus it also drives us to the opinion that for design U-values of windows, at least for those with effective low-E coatings, the best thing is to use an external surface heat transfer coefficient corresponding to an average wind speed during the coldest period. In Lithuania the coldest days period is the period of five coldest days in fifty years and its average temperature is taken as a design temperature for heating.

As we can see from Table 3 and Fig 2, the U-values for ordinary IG unit without any low-E coating have a slight tendency to fall down with dropping down of an outdoor temperature. For this type of units there is no reason to introduce a concept of a design U-value. This makes sense only for IG units with effective low-E coatings, up to emissivity value of $\varepsilon_{n}=0,2$. In this case, if to take a declared value instead of a design value, this could lead to a mistake calculating heat losses of ordinary apartments in middle floors of dwellings up to $7 \%$ of the total heat losses. For public buildings having a

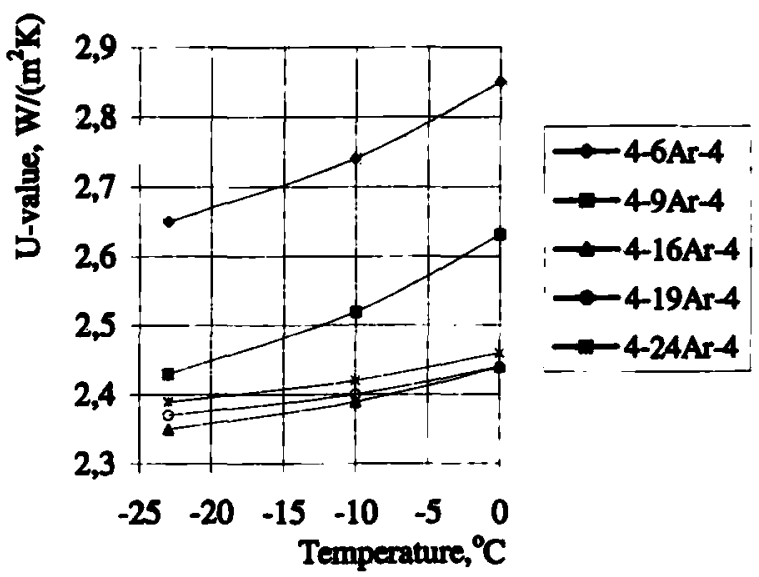

Fig 4. The dependence of U-values of IG units without low-E coating on outdoor temperature and spacer width

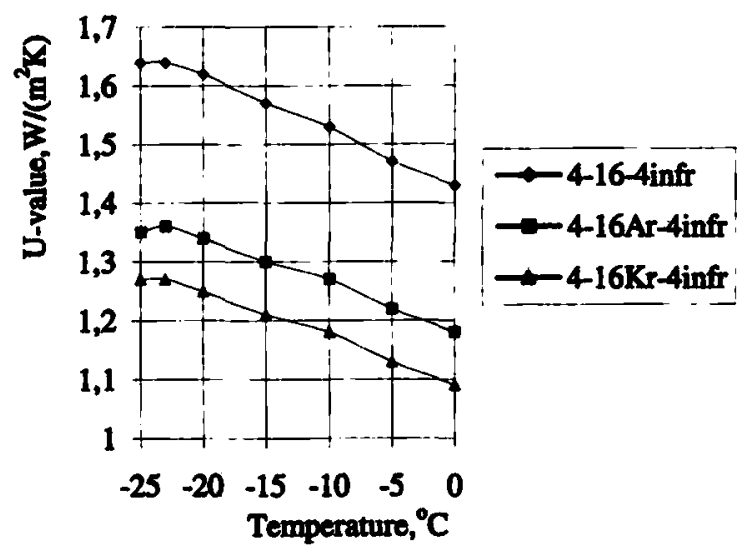

Fig 5. The dependence of U-values of IG units with $\varepsilon_{n}=0,04$ low-E coating in outdoor temperature

large glazed areas a situation can be much worse. Such a possible situation would be unacceptable.

To learn the reasons why the IG units with effective low-E coatings have lost their thermal protective values with lowering of outdoor temperature, we have calculated ( according to procedures in [16] ) the constituents of a heat transfer U: radiation conductance $h_{r}$, gas conductance $h_{g}$, thermal conductance of a gas space $h_{s}$ and a total thermal conductance of glazing unit $h_{t}$. The calculation results are placed in Table 4 and according to these results graphs in Fig 6 have been drawn.

Why does with dropping of outdoor temperature the U-value of an IG unit become worse, at least for those with low-emissivity values of coatings, can be explained taking into account such remarks:

- with lowering of the outdoor temperature, the difference between gas conductance $h_{g}$ due to a change of an emissivity value $\varepsilon$ of coating is almost stable and as a rule for coatings with a low-emissivity values it is much bigger than a difference between radiation conductance values $h_{r}$;

- with lowering of emissivity values $\varepsilon$, radiation conductance values $h_{r}$ due to a change of surface temperatures become closer to each other; 
Table 4. Calculated heat transfer coefficients, radiation and gas conductance through IG unit (spacer width $16 \mathrm{~mm}$, filled with Argon) with various emissivities $\varepsilon$ when outdoor temperatures are 0 and $-23{ }^{\circ} \mathrm{C}$

\begin{tabular}{|c|c|c|c|c|c|}
\hline $\begin{array}{c}\mathrm{Ar} \\
16 \mathrm{~mm}\end{array}$ & $\begin{array}{c}h_{r} \\
\mathrm{~W} / \mathrm{m}^{2} \cdot \mathrm{K}\end{array}$ & $\begin{array}{c}h_{g} \\
\mathrm{~W} / \mathrm{m}^{2} \cdot \mathrm{K}\end{array}$ & $\begin{array}{c}h_{s} \\
\mathrm{~W} / \mathrm{m}^{2} \cdot \mathrm{K}\end{array}$ & $\begin{array}{c}h_{t} \\
\mathrm{~W} / \mathrm{m}^{2} \cdot \mathrm{K}\end{array}$ & $\begin{array}{c}U \\
\mathrm{~W} / \mathrm{m}^{2} \cdot \mathrm{K}\end{array}$ \\
\hline \multicolumn{6}{|l|}{$\varepsilon=0,04$} \\
\hline $\begin{array}{c}0^{\circ} \mathrm{C} \\
4,5 \mathrm{~m} / \mathrm{s}\end{array}$ & 0,2403 & 1,1756 & 1,4159 & 1,4001 & 1,131 \\
\hline $\begin{array}{c}-23{ }^{\circ} \mathrm{C} \\
2,5 \mathrm{~m} / \mathrm{s}\end{array}$ & 0,2097 & 1,6032 & 1,8129 & 1,787 & 1,364 \\
\hline \multicolumn{6}{|l|}{$\varepsilon=0,08$} \\
\hline $\begin{array}{c}0^{\circ} \mathrm{C} \\
4,5 \mathrm{~m} / \mathrm{s}\end{array}$ & 0,4539 & 1,1655 & 1,6194 & 1,5988 & 1,257 \\
\hline $\begin{array}{l}-23^{\circ} \mathrm{C} \\
2,5 \mathrm{~m} / \mathrm{s}\end{array}$ & 0,396 & 1,5919 & 1,9879 & 1,9569 & 1,461 \\
\hline \multicolumn{6}{|l|}{$\varepsilon=0,2$} \\
\hline $\begin{array}{c}0^{\circ} \mathrm{C} \\
4,5 \mathrm{~m} / \mathrm{s}\end{array}$ & 1,0424 & 1,1346 & 2,177 & 2,1397 & 1,569 \\
\hline $\begin{array}{l}-23^{\circ} \mathrm{C} \\
2,5 \mathrm{~m} / \mathrm{s}\end{array}$ & 0,9091 & 1,5564 & 2,4655 & 2,4179 & 1,704 \\
\hline \multicolumn{6}{|c|}{$\varepsilon=0,84$ ordinary float glass } \\
\hline $\begin{array}{c}0{ }^{\circ} \mathrm{C} \\
4,5 \mathrm{~m} / \mathrm{s}\end{array}$ & 3,0793 & 0,9891 & 4,0684 & 3,9402 & 2,36 \\
\hline $\begin{array}{l}-23^{\circ} \mathrm{C} \\
2,5 \mathrm{~m} / \mathrm{s}\end{array}$ & 2,6757 & 1,3628 & 4,0385 & 3,9121 & 2,331 \\
\hline
\end{tabular}

- when the emissivity value $\varepsilon$ of a coating becomes equal to about 0,8 , only then an increase of a gas conductance $h_{g}$ approximately becomes equal (compensates) to a decrease of radiation conductance $h_{r}$ as outdoor temperature has changed.

If to look at Fig 6, it is clearly seen that the constituent of a radiation of a heat transfer through IG unit with lowering of an emissivity value $\varepsilon$ of coating is constantly diminishing, while the gas constituent which includes convection and conduction at the same conditions remains almost stable.

\section{Conclusions and recommendations}

After a short revue of $U$-values of different IG units presented in Table 3 and Figs $2-5$ we have made the following conclusions:

1. A gas filling of IG unit practically does not have any influence on dependence of U-value on the outdoor temperature change. There is almost no influence of a spacer width on dependence of $U$-value on the outdoor temperature. This influence is mostly contributed by emissivity of low-E coating and is very intense for IG units with very effective low-E coatings. With growing of $\varepsilon_{n}$ value an influence of outdoor

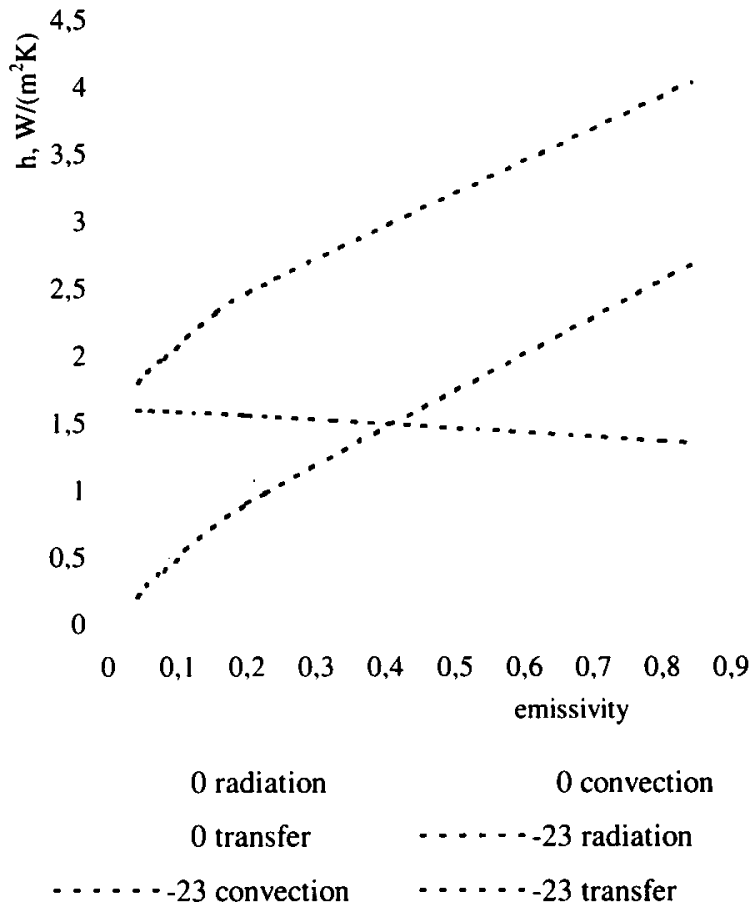

Fig 6. Radiation and gas (convection and conduction) constituents of a heat transfer through IG unit (filled with Argon gas, spacer width $16 \mathrm{~mm}$ ) with various emissivities $\varepsilon$ when outdoor temperatures are 0 and $-23^{\circ} \mathrm{C}$

temperature on a change of U-value is diminishing.

2. Differences between the declared and design values reach on average up to $17 \%$ for double glazed IG units with one low-E coating. This is quite a big inadequacy.

3. Calculation of heat losses for building using declared $\mathrm{U}$-values of windows instead of design values could lead to a mistake up to $7 \%$ of a total heat losses of ordinary apartment. For public buildings with large glazed areas a calculation mistake could reach over $10 \%$.

4. With a situation above, choosing a power rate for a heating source of a building or apartment, a danger arises not to maintain a correct indoor microclimate during the coldest winter period, especially if a safety factor of a heating source is taken as 1,1 (ie $10 \%$ ).

We have found being reasonable to recommend this:

1. In order to avoid the above-mentioned and other possible unexpected consequences, in case if for very effective windows declared U-values would be used instead of design, it makes sense to introduce a concept of design U-value for windows in Lithuania.

2. Also it would be reasonable to introduce an obligatory design U-value for IG units with (effective) low-E coating(s) which would be announced together with a declared value, or at least in case of a client or contractor claim. 


\section{List of symbols}

\begin{tabular}{|c|c|c|}
\hline$d$ & thickness & $\mathrm{m}$ \\
\hline$\lambda$ & thermal conductivity & $\mathrm{W} /(\mathrm{m} \cdot \mathrm{K})$ \\
\hline$R$ & thermal resistance & $\mathrm{m}^{2} \cdot \mathrm{K} / \mathrm{W}$ \\
\hline & thermal transmittance & $\mathrm{W} /\left(\mathrm{m}^{2} \cdot \mathrm{K}\right)$ \\
\hline & $\begin{array}{l}\text { external surface heat transfer } \\
\text { coefficient }\end{array}$ & $\mathrm{W} /\left(\mathrm{m}^{2} \mathrm{~K}\right)$ \\
\hline & $\begin{array}{l}\text { internal surface heat transfer } \\
\text { coefficient }\end{array}$ & $\mathrm{W} /\left(\mathrm{m}^{2} \mathrm{~K}\right)$ \\
\hline & $\begin{array}{l}\text { total thermal conductance of } \\
\text { glazing unit } \\
\text { thermal conductance of a gas }\end{array}$ & $\mathrm{W} /\left(\mathrm{m}^{2} \mathrm{~K}\right)$ \\
\hline & $\begin{array}{l}\text { thermal conductance of a gas } \\
\text { space } \\
\text { radiation conductance of a gas }\end{array}$ & $\mathrm{W} /\left(\mathrm{m}^{2} \mathrm{~K}\right)$ \\
\hline & space & $\mathrm{W} /\left(\mathrm{m}^{2} \mathrm{~K}\right)$ \\
\hline & $\begin{array}{l}\text { gas conductance of a gas space } \\
\text { width of a gas space }\end{array}$ & $\mathrm{W} /\left(\mathrm{m}^{2} \mathrm{~K}\right)$ \\
\hline & $\begin{array}{l}\text { width of a gas space } \\
\text { absolute temperature }\end{array}$ & $\begin{array}{l}\mathrm{m} \\
\mathbf{K}\end{array}$ \\
\hline$T_{m}$ & absolute mean temperature & K \\
\hline$N u$ & Nusselt number & - \\
\hline$G r$ & Grashof number & - \\
\hline $\operatorname{Pr}$ & $\begin{array}{l}\text { Prandtl number } \\
\text { density }\end{array}$ & $\overline{\mathrm{kg} / \mathrm{m}^{3}}$ \\
\hline & dynamic viscosity & $\mathrm{kg} /(\mathrm{m} \cdot \mathrm{s})$ \\
\hline & specific heat capacity & $\mathrm{J} /(\mathrm{kg} \cdot \mathrm{K})$ \\
\hline & $\begin{array}{l}\text { surface normal infrared } \\
\text { emissivity }\end{array}$ & - \\
\hline & $\begin{array}{l}\text { surface corrected infrared } \\
\text { emissivity }\end{array}$ & \\
\hline & Stefan-Boltzmann's constan & $\mathrm{W} /\left(\mathrm{m}^{2} \mathrm{~K}^{4}\right)$ \\
\hline
\end{tabular}

\section{References}

1. Barkauskas, V.; Stankevičius, V. Building thermal physics (Pastaty atitvaru šiluminé fizika). Kaunas: Technologija, 2000. 286 p. (in Lithuanian).

2. STR 2.01.03:1999 Declared and design values of thermaltechnical characteristics of building materials and products (Statybinių medžiagu ir gaminių šiluminių techniniu dydžiu deklaruojamosios ir projektinés vertés). 1999. 24 p. (in Lithuanian).

3. STR 2.05.01:1999.Thermal technique of envelopes of the buildings (Pastatu atitvaru šiluminè technika). 1999. 133 p. (in Lithuanian).

4. Elmahdy, A. H. and Cornick, S. M. New technology in the window industry.

Located at http://www.nrc.ca/irc/bsi/88-5_E.html
5. Brown, W. C. and Ruberg, K. Window performance factors. Located at http://www.nrc.ca/irc/bsi/88-2_E.html

6. Dyrgøl, S. Heat transfer in rockwool modelling and method of measurement: $\mathrm{PhD}$ thesis, part 1: The heat effect of natural convection on heat transfer in fibrous materials; Technical University of Denmark, Department of Buildings and Energy. Copenhagen, 1998. $81 \mathrm{p}$.

7. Rousseau, M. Z. Windows: overview of issues. Located at http://www.nrc.ca/irc/bsi/88-1_E.html

8. Chahroudi, D. The future of high-performance glazing. Solar age, February 1986, p. 21-26.

9. Owens, P. G. T. Low emissivity coatings on glass in windows. Building Control, September/October 1985, p. 4245.

10. Swanson, J. G. What is the outlook for low-E glass? Glass digest, May 1986, p. 60-64.

11. Valdes, N. How much do you know about low-E? Glass digest, February 1987, p. 97-100.

12. RSN 143-92. Thermal technics of building enclosures (Pastatu atitvaru šiluminė technika). Vilnius, 1992. $71 \mathrm{p}$. (in Lithuanian).

13. COST ACTION C13. Glass and interactive building envelopes. Kaunas, 2001. 57 p. (in Lithuanian).

14. Klimkevičius, A. Lithanian window production and market. Window modernisation in the Baltic countries: problems and opportunities (Langu modernizavimas Baltijos šalyse: problemos ir galimybès). Kaunas: Technologija, 2000. 51p. (in Lithuanian).

15. Katz, S. M. Thermal insulating materials resistive to high temperatures (Высокотемпературные теплоизоляционные материалы). Moscow: Metalurgia, 1981. 232 p. (in Russian).

16. LST EN 673+al:2000 en. Glass in building. Determination of thermal transmittance ( $U$ value). Calculation method (Statybinis stiklas. Silumos perdavimo nustatymas (U vertè). Skaičiavimo metodas). 2000. 22 p.

17. WINDOW 4.1: Program description. Lawrence Berkeley Laboratory, USA. March, 1994. 79 p.

18. Blomberg T. U-value for a window accouting for the wall. Building physics in the Nordic countries, Vol 1, Copenhagen 1993. p. 73-80.

19. ISO $8301: 1991(\mathrm{E})$. Thermal insulation - Determination of steady-state thermal resistance and related properties - heat flow meter apparatus.

20. RSN 156-94. Building climatology (Statybinè klimatologija). Vilnius, 1995. 136 p. (in Lithuanian). 